University of Michigan Law School

University of Michigan Law School Scholarship Repository

\title{
Reletting on Abandonment by Tenant as Surrender by Operation of Law
}

\author{
Ralph W. Aigler \\ University of Michigan Law School
}

Available at: https://repository.law.umich.edu/articles/1337

Follow this and additional works at: https://repository.law.umich.edu/articles

Part of the Property Law and Real Estate Commons

\section{Recommended Citation}

Aigler, Ralph W. "Reletting on Abandonment by Tenant as Surrender by Operation of Law." Mich. L. Rev. 15 (1917): 659-60.

This Response or Comment is brought to you for free and open access by the Faculty Scholarship at University of Michigan Law School Scholarship Repository. It has been accepted for inclusion in Articles by an authorized administrator of University of Michigan Law School Scholarship Repository. For more information, please contact mlaw.repository@umich.edu. 
Reletring on Abandonment by Tenant as Surrender by Operation or I.AW.-Among the very many difficult problems arising under the STATUTE of FRAUDS not the least troublesome has been that of surrender of estates by "operation of law." The Statute (29 Car. II, c.3,\$3,) provided that "no leases $* * *$ shall $* * *$ be assigned, granted, or surrendered, unless it be by deed or note in writing, *** or by act and operation of law." Under a number of varying situations it has been held that a surrender by operation of law had been accomplished. See 2 TIFfany, LANDloRd and Tenant, §Igo. In Lyon v. Reed, 13 M. \& W. 285, Baron PARKE, after referring to a number of such situations, said: "It is needless to multiply examples; all the old cases will be found to depend on the principle to which we have adverted, namely, an act done by or to the owner of a particular estate, the validity of which he is estopped from disputing, and which could not have been done if the particular estate continued to exist. The law there says, that the act itself amounts to a surrender. In such case it will be observed there can be no question of intention. It takes place independently, and even in spite of intention."

Perhaps the most common situation giving rise to a claim of surrender by operation of law is the re-letting of the premises to a new tenant after a lessee has abandoned them before the end of his term, notice of intention ta continue to look to the original lessee to make up deficiencies, if any, sometimes being given and sometimes not. Whatever may be said as to the proper holding on sound legal reasoning, it is certainly true that the courts are holding that such re-letting does not necessarily bring about a surrender by operation of law; particularly is this true where the lessor has given notice to the first lessee that the new lease is made on his account, or without prejudice to any claims against him on the original lease. Rucker v. $\mathrm{Ma}$ son (Okla. 1916), 161 Pac. 195, I5 Mrce. L. Rev. 357; Hickman v. Breadford (Iowa 1917), $162 \mathrm{~N} . \mathrm{W} .53$.

If such surrenders are, as said by Baron PARKE, founded upon estoppels and are wholly independent of intention, it would seem that cases of the above 
character must be considered as incorrectly decided. The nè lease must be taken, at least as between the parties thereto, as valid; but how can it be valid as against the lessor unless the first lease has somelow been gotten out of the way? Can he be allowed to say that he has two present leases of the same premises running along concurrently? But the courts are far from agreement with Baron PARKE's doctrine that intention has nothing to do with surrenders by operation of law. See Van Renssalaer's Heirs v. Pensiman, 6 Wend. 569; Smith v. Kerr, 108 N. Y. 31, 15 N. E. 70; Thomas v. Zumbalen, 43 Mo. $47 x$; Jolnsson v. Northern Trust Co., 265 I11. 263 , 106 N. E. 814; O'Neil v. Pearse, 87 N. J. L. 382, 94 Atl. 312; Atter v. Penn, 99 Pa. 370. See also Nichells v. Atherstone, To Q. B. 944; Zick v. London United Tramzoays, Limited [1908], 2 K. B. I26. And that surrenders by operation of law do not necessarily rest upon estoppels at all is the opinion expressed in an interesting note in 5 IrISH Jurist II7. Cf. 2 TIfFany, Landiord and TenANT 1322.

But whether the true explanation is estoppel or necessary implication from rertain facts not amounting to a technical estoppel, it is difficult to see how in the usual case of re-letting after abandonment by a tenant before the end of his term the old term can be said to be continuing. And the mere giving of notice to the old tenant that the new lease shall not act as a release of liability would seem to make no real difference. An agreement by the original lessee may well produce a different.result. Whatever may, be said as to the necessity for estoppel to bring about. a surrender by operation of law, it would: seem quite proper to say that, where all the. elements of an estoppel to assent the continuance of the relation of landlord and tenant are present there has been a surrender, by operation of law. It is submitted that in the type of cases under discussion there is such an estoppel. .

The prevailing doctrine undoubtedly is due very largely to a desire on the part of the courts to avoid imposing what.seems to be a hardship upon the landlord. "It should be noted that a lease can be -very easily so worded that the lessor may be protected and at the same time avoid the difficulties herein referred to. See, however, Whitcomb v. Brant (N. J. 19ז7), 100 Átl. I75, where such a provision in a lease led to- another very interesting difficulty, the lessor on re-letting getting a higher rent than provided for in the original lease. It was held that the lessor did not need to account to the first lessee for such excess.

R. W. A. 